\title{
Swift and Sure Justice? Mode of Trial for Causing Death by Driving Offences
}

by $\operatorname{Dr}$ Steven Cammiss (Senior Lecturer in Law) and Professor Sally Kyd Cunningham, School of Law, University of Leicester,

Corresponding author:

Steven Cammiss

School of Law

University of Leicester

University Road

Leicester

LE1 7RH

Tel: 01162522468

Fax: 01162525023

Email: sc293@le.ac.uk

Manuscript word count:9,902, including title, abstract, key words and references.

Abstract

In this paper we present empirical evidence on the allocation of causing death by driving offences to explore the inter-relationship between different criminal justice policy goals. Specifically, we look at the decision-making of the various parties 
involved in such cases: the prosecution in recommending the venue for trials; the defence in deciding whether to plead guilty or to elect trial in the Crown Court; and magistrates in deciding whether to accept jurisdiction or commit to the Crown Court. These decisions are then set within the context of the Government's desire to achieve 'Swift and Sure Justice', promote correct allocation decisions for either-way offences, and reduce the number of 'cracked trials'. The data show that many of these cases are committed to the Crown Court, only to receive a sentence within the powers of magistrates, and that the proportion of cases where this happens is higher than for mainstream offences. Our contention is that although there is something special about the offences under discussion, in that the fact that a death is involved raises issues as to how justice is seen to be done, undue focus is placed upon 'swift justice' which generates problems later in the process.

Key Words

Causing death by driving - Mode of Trial - 'Swift and Sure Justice'

\section{Introduction}

The motor vehicle has liberated individuals by enabling them to travel where they choose yet, in addition to numerous advantages created by its invention, it has brought with it disadvantages of equal significance, such as pollution and congestion. Perhaps the most damaging feature of motor vehicles is their ability to cause death and injury. In 1913 , when there were 106,000 cars on the roads in the UK, there were 1,743 fatal road traffic accidents (Emsley 1993, 358-359). This figure rose once cars became 
more available, peaking at 7,407 in Great Britain in 1973 (Perkin 1976, 227). While the initial policy reaction to road safety issues was 'strangely muted' (Foreman-Peck 1987, 269), laws were later passed to regulate the use of motor vehicles, with the aspiration to reduce death and injury. Such laws have become increasingly punitive over the decades and, although road deaths have decreased dramatically to 1,754 in 2012 (Department for Transport 2013), it is impossible to measure how much this ought to be attributed to enforcement of criminal offences, and how much to measures such as technological and engineering improvements.

This article discusses two new causing death offences created by the Road Safety Act 2006, ostensibly to assist in deterring bad driving and to close the 'justice gap' by providing higher sentences for drivers who cause death but whose driving does not fall within the existing offence of causing death by dangerous driving (Cunningham 2007). These new offences are unusual in that they are offences which punish the causing of death, and as such could be classed as 'homicide' offences, yet they are constructive crimes, meaning that serious offences have been created from existing, fairly minor, regulatory offences, with nothing more required to be proved in terms of blameworthiness relating to the causing of death. They are also unusual in that although they reflect the harm of death in their offence label, they are both offences triable either-way, meaning that they can be tried in either the Crown or magistrates' court. This latter characteristic is our focus, and we explore the decision-making processes involved in determining mode of trial in such cases, and assess how this fits with policies relating to mode of trial more generally. We draw on the results of an empirical study of the operation of the new offences to conclude that there is something special about these unusual offences so that the way they are processed is 
not representative of mode of trial decision-making generally, although there are similarities with 'mainstream' offences. Further, we show decision-making conflicts with policy makers' desire to reduce the number of cases being committed to the Crown Court. We begin with a summary of the new offences, before presenting data on mode of trial decision-making for these new offences. We then place these findings within the context of the government's policy of Swift and Sure Justice before discussing the implications of the research. Finally, we conclude that swift and sure justice takes a back-seat to the desire for these offences to be dealt with in the Crown Court, where the gravitas of proceedings, rather than any ultimate sentence, is symbolic in reflecting the harm done.

\section{Causing Death by Driving Offences}

The Road Safety Act (RSA) 2006 came into force in August 2008, creating two new 'vehicular homicide' offences under sections 2B and 3ZB of the Road Traffic Act (RTA) 1988. Causing death by careless driving (CDCD) under s.2B follows the offence construction of the existing offence of causing death by dangerous driving (CDDD) in requiring that death results from an underlying driving offence. CDDD is an indictable only offence carrying a maximum penalty of 14 years' imprisonment (RTA 1988, s.1). Prior to the creation of CDCD, if careless, but not dangerous, driving caused death, the only possible offence to charge was the summary only offence of careless driving, punishable by a fine and penalty points. This 'gap' in sentencing between the two offences caused distress to bereaved families because the fact of death received little attention by the courts (Cunningham, 2007). The new offence recognises the fatality in the offence label and provides a maximum penalty 
of five years' imprisonment. It punishes bad driving that causes death ranging from 'momentary inattention' to driving falling just short of dangerous driving.

The second offence, created by s.3ZB, punishes causing death by driving whilst uninsured, unlicensed or disqualified from driving (the shorthand of 'causing death by unlawful driving' (CDUD) will be used hereafter). This offence covers drivers who are involved in a fatal collision who are deemed to be responsible because they should not have been driving and carries a maximum sentence of two years' imprisonment.

Both CDCD and CDUD are triable either-way offences, rather than summary or indictable only offences. Summary offences stay in the magistrates' court while indictable only offences must be sent to the Crown Court. For triable either-way offences magistrates' courts must decide on the appropriate venue for any subsequent trial, retaining jurisdiction only if they believe their sentencing powers (a maximum of six months' imprisonment for a single offence) are sufficient to deal with the particular example of the offence under consideration. This will be expanded on later. Originally it was proposed that CDCD be indictable only, but following consultation it was concluded that:

having considered the responses on this issue, in particular from Magistrates and legal professionals who deal with such cases, we agree that many cases of this nature will remain suitable for trial in the Magistrates Courts and they should continue to be heard there where appropriate. Of course, where the facts of the case indicate that summary trial is not appropriate, the case would be able to be heard in the Crown Court (Home Office, 2005: 5). 
Some responses to the consultation also suggested that the maximum penalty ought to be two years' imprisonment, but this was rejected (ibid). Conversely, the initial proposal for the CDUD offence was for a maximum penalty of five years' imprisonment, which was reduced to two years following consultation. Initially, no recommendation was made on mode of trial, and views on this were sought:

\footnotetext{
Some respondents suggested that the offence should be triable either-way and should be subject to a lower maximum penalty. Several respondents felt that 5 years would be disproportionate to the relevant offending behaviour and would be used infrequently. The Government has been persuaded by this argument and therefore recommends a lower maximum penalty of 2 years which would recognise the fact that the driver has placed other road users at unacceptable risk but balances this with the recognition of the fact that the standard of driving need not have been at fault. (Ibid: 8)
}

Both offences are the subject of a definitive sentencing guideline from the Sentencing Council (Sentencing Guidelines Council, 2008a). The Guidelines categorise cases of CDCD into three levels. The top category covers the most serious cases of CDCD falling just short of dangerous driving; the bottom category covers cases of momentary inattention with no aggravating factors; and the middle category catches all that fall in between. Those in the bottom category should receive a community order, whilst the starting point for those in the middle category is a custodial sentence. Padfield uses CDCD as an illustration of cases which straddle the custody threshold 'quite dramatically' (Padfield, 2011: 605), causing difficulty for the courts in applying the Guidelines (Padfield, 2011: 606). Given this, one could expect the magistrates' court to have problems determining mode of trial for these cases. 
The Guidelines for CDUD distinguish between disqualified driving on the one hand, and uninsured and unlicensed driving on the other. If the defendant was unlicensed or uninsured and there are no aggravating factors, the starting point is a medium community order. Where the defendant was disqualified from driving the starting point is 12 months imprisonment (Sentencing Guidelines Council, 2008a).

The Guidelines for both offences suggest that, for the least serious offences, magistrates' court disposal will be appropriate and that magistrates should be encouraged to retain jurisdiction. We will shortly see how these Guidelines do not seem to operate effectively within the mode of trial hearing. Before doing this, we need to outline the process for determining mode of trial and explain the methods adopted in the study.

\section{Mode of trial}

The study explored cases that were processed before the implementation of the reforms contained in Schedule 3 of the Criminal Justice Act 2003, and the law as described here has been amended in a number of important ways (see below). The process to be followed is that defendants must enter a plea to the charges (s 17A of the Magistrates' Court Act (MCA) 1980) and venue is only considered if the defendant pleads not guilty or declines to indicate a plea. Magistrates must decide if they can accept jurisdiction or send the case to the Crown Court, having regard to the nature and seriousness of the offence, whether their sentencing powers are sufficient, and any other relevant factors (s 19 of the MCA 1980), and Magistrates' Courts Sentencing Guidelines (Sentencing Guidelines Council, 2008b). Both the prosecution 
and defence can make representations regarding venue. If the magistrates accept jurisdiction the defendant retains the right to elect jury trial in the Crown Court.

\section{The study}

In an attempt to establish how the new offences are operating in practice, and to explore how they have affected the decision-making process in the prosecution of death by driving cases, access was gained to CPS files and police files in relation to a total of 122 road death incidents (emanating from the CPS centrally and three police forces; see below), and semi-structured interviews were conducted with 27 individuals: eight police officers from these three forces and a fourth force; 13 CPS lawyers from nine CPS Areas; four barristers external to the CPS; and two defence solicitors. An application to interview magistrates and judges was refused.

In 2009, 54 CDUD offences were charged in England and Wales (CPS statistics provided to the authors). Given the scarcity of the offence researchers would be unlikely to encounter any significant number of such cases from a random selection of fatal collisions files; a more targeted approach was taken by securing agreement from CPS headquarters to access 14 files relating to such charges. These came from eight different CPS areas across England and Wales, selected by the researchers according to the likelihood of being able to conduct interviews with the lawyers involved, and were accessed at CPS offices in London.

In addition, in order to gather data on how investigations and prosecutions of fatal collisions are conducted, and how the existence of the new offences was affecting the 
exercise of investigative and prosecutorial discretion, access to police files relating to fatal collisions in three police forces was secured. Two of these forces (A and B) were mainly rural in nature, containing a number of large towns and one large urban conurbation, while the third force (C) is mainly urban in character. Access was granted to 30 files relating to fatal road traffic collisions occurring in Force A. These were selected by the force itself from fatalities occurring from September 2008 onwards, as per a data processing agreement ${ }^{1}$ (the number of fatalities occurring in that force area in 2009 was 36). Eighteen of these files led to charges for at least one of the causing death offences, and 12 resulted in no further action (NFA). In Force B every file completed since August 2008 was accessed, amounting to 46 files: 22 resulting in a criminal charge and 24 resulting in NFA. In Force C, 32 files were accessed: 15 resulting in a charge of some form and 17 resulting in NFA. These were selected on the basis of the files being available to the researcher in electronic format as those only existing in hard copy were in storage. As a result, the sample in that force was made up of more recently investigated cases (there were 50 fatal collisions occurring in Force $\mathrm{C}$ in 2010). Given the low number of offences charged, there are an inevitable low number of cases from which to draw our conclusions, a fact that we could do little to address. However, combining the data with interviews means that we are able to draw reasonable, if a little tentative, conclusions from the evidence.

\footnotetext{
${ }^{1}$ Access to files in two of the forces could only be secured through the signature of a protocol under which the researchers made a number of assurances to the police with regards to the use and storage of data. This included an undertaking of confidentiality and a right for the Chief Constable to restrict publication of findings.
} 
Further, access was also given to a spreadsheet of cases maintained by the CPS centrally over a twelve month 'monitoring period' (October 2008 to October 2009). During this time CPS Prosecutors were asked to inform headquarters of any cases where, having received a file for a charging decision, CDCD or CDUD was considered as a possible charge. These cases were then tracked through to completion and it was documented whether the cases were charged or not and, if so, what the outcome at court was. This provides some valuable information about the early operation of these offences, although no qualitative data about the nature of the offence is included.

An important point to note here concerns the limitations of the fieldwork data, limitations that are inherent in research based upon file analysis. For a number of mode of trial recommendations/decisions, reasons were not recorded on the CPS file, or if reasons were given, these were brief and unhelpful. The CPS monitoring data, in particular, contained an absence of important qualitative information. However, there is a sufficient number of cases where full reasons were recorded so as to give an important insight into decision-making. Within the files for some of the earliest prosecutions extensive endorsements were made, presumably as prosecutors were familiarising themselves with the new offence and wanted to record their reasoning. Additionally, for cases sent to the Crown Court, it was not always possible to tell whether this was because the defendant elected or the bench declined jurisdiction. Combining case data and interviews, however, alleviates to some extent these limitations, in that the interviews provide alternative data on decision-making practices. Furthermore, a file analysis method provides a sufficiently large sample; 
direct observation of these cases would be impracticable as there are relatively few cases prosecuted.

\section{Findings}

For ease of analysis, we will initially explore mode of trial decisions for the CDCD cases, before turning to the CDUD cases. Table 1 sets out the relevant data from police and CPS files. We have excluded cases where CDCD and/or CDUD were charged alongside an indictable-only offence, since these cases did not call for a mode of trial decision to be taken. This leaves 22 CDCD and 7 CDUD cases.

\section{Causing death by careless driving}

Many of the police file CDCD cases resulted from momentary inattention, suggesting that they were suitable for summary trial, yet most were sent to the Crown Court. Starting with the participating police/CPS areas, of the 22 cases in the sample, only four were sentenced at the magistrates' court after a guilty plea, with the remainder sent to the Crown Court. Of these 18 cases, 11 received a sentence within the powers of the magistrates' court, a proportion much higher than for triable either-way cases generally (Moreton (2012) reported a figure of at least 35 per cent). Late guilty pleas were prevalent in the Crown Court, the data suggesting that some defendants were awaiting expert opinion before deciding on plea. Only in four cases did the defendant maintain a not guilty plea, with three going to trial (one defendant was acquitted), and the CPS dropped the charges in the other case. 
Turning to the CPS monitoring data, of the 55 cases where CDCD was the most serious charge, 25 stayed in the magistrates' court, with the remaining 30 committed to the Crown Court. We unfortunately do not have data on whether these cases were sent on the basis of magistrates declining jurisdiction or the defendant electing. Guilty pleas were entered in all but one case, while the defendant who maintained innocence was convicted after trial. Returning to committals, there are good reasons, explored later, for believing that not all of these were for sentence, but rather that defendants were initially pleading not guilty only subsequently to plead guilty after the bench declined jurisdiction. Of the 30 cases sent to the Crown Court, 15 defendants were sentenced within the powers of the magistrates' court, a proportion much higher than for either-way cases generally. While the numbers are small, so care should be taken in interpreting these findings, we suggest that the police/CPS areas studied are not representative of national practices (in that a higher proportion of cases from the police/CPS case sample were sent to the Crown Court compared to the national CPS monitoring data), and that local court cultures exist. This is unsurprising as it accords with previous research (Cammiss, 2007; Herbert, 2004).

\section{Causing death by unlawful driving}

Starting with the study sample, all 14 CDUD cases were heard at the Crown Court. Seven of these were sent to the Crown Court because they were linked to an indictable only offence, and often the CDUD charge was later dropped as part of a plea bargain (Kyd Cunningham 2013). Table 1, therefore, only includes 7 cases where CDUD was the most serious charge. For these, the prosecution usually recommended the magistrates decline jurisdiction. However, in two cases the prosecution 
recommended the bench retain jurisdiction; in one of these the defendant elected, and in the other the bench disagreed and declined jurisdiction. Turning to disposals, five defendants were sentenced within the powers of the magistrates' court, no evidence was offered in one case and one defendant received a sentence exceeding the magistrates' maximum (an eight month term in a Young Offender Institution).

In the CPS monitoring data, there were 17 cases where CDUD was the most serious charge (there were 44 cases where CDUD was considered, but for a large number of these a more serious offence was also charged). Of these, five were sentenced by magistrates after a guilty plea. The remaining 12 were committed to the Crown Court for trial or sentence. In the 17 cases, 15 defendants pleaded guilty at some stage, with one defendant convicted after trial (the data is unclear on a further defendant). Again, we can presume that a number of defendants pleaded not guilty only to subsequently change their plea in the Crown Court. Of the 12 cases sent to the Crown Court, eight received a sentence within the powers of magistrates and there is a further case for which sentencing data was unavailable.

\section{Discussion}

It seems from both data sources that a very large proportion of cases are being sent to the Crown Court only to receive sentences within the powers of magistrates, although the situation does not quite appear to be the same as for domestic burglary, section 20 assault or violent disorder which are routinely sent to the Crown Court irrespective of case features (Cammiss, 2007). However, once these cases reach the Crown Court, they often receive sentences within the powers of the magistrates' court, thereby 
raising doubts about the initial allocation decision. For mode of trial generally, we can theorise that subsequent courtroom processes, such as plea bargains, plea changes, or witnesses not coming up to proof, can explain many of these cases (Cammiss, 2006). However, given the large number of guilty pleas in the sample, some of these arguments may not apply. While there is certainly evidence of sentencing discounts here, this cannot account for all the cases where defendants received sentences within the powers of magistrates. Rather, the evidence suggests that magistrates are too quick to send cases to the Crown Court, for reasons that we will explore shortly. Additionally, there are a high number of guilty pleas in the Crown Court. While not all of these will be 'cracked trials' (a change of plea on the day of the trial), they still suggest that something is going wrong in the process. We will see later that this is not a case of defendants 'playing the system', but could rather be an unintended consequence of the 'swift and sure justice' policy. Mode of trial is decided early in the process so defendants may offer a plea in an information defecit. Although prosecution disclosure will have taken place, there remains the issue of whether expert opinion could be useful, and so a not guilty plea may be entered initially and an expert commissioned.

Generally, a number of cases sent to the Crown Court receive sentences within the powers of magistrates' courts (Hedderman and Moxon, 1992; Moreton, 2012) and for these causing death by driving offences the problem is greater than usual. The general position has worried governments and policy makers for some time now (Cammiss, 2006); magistrates may decline jurisdiction believing that their sentencing powers are insufficient (or defendants may elect jury trial to take advantage of the higher Crown Court acquittal rate) but these decisions have resource implications (Hedderman and 
Moxon, 1992; Riley and Vennard, 1988). Crown Court trial is more expensive and there is a problem with Crown Court delays. There are several explanations for Crown Court cases receiving a sentence within magistrates' powers. Herbert noted how magistrates seemed to be, at best, ambivalent about a proposal to increase their sentencing powers (Herbert, 2003). In essence, they believed they were already working at the edge of their competence, although recent evidence suggests magistrates would welcome an increase in their sentencing powers (Ipsos Mori, 2011), a proposal supported by the Magistrates' Association (Magistrates' Association, 2012). Having to deal with cases involving death would, to many magistrates, raise similar issues. McBarnet's (1981) observation still holds: magistrates' courts are infused with an air of triviality, complex points of law or evidence are not appropriate and serious cases should be in the Crown Court. Causing death by driving offences are problematic for magistrates; they are homicide offences and could involve complex forensic evidence (possibly disputed) (Cunningham, 2008). It is unsurprising that magistrates decline jurisdiction, particularly if the victim's family feel that trial in the magistrates' court is inappropriate. This also explains many prosecution recommendations, as in the following file note:

Given the Sentencing Guidelines... I cannot say that this case must go to the Crown Court. Having said that if [the defendant] does not plead guilty at the earliest opportunity in the magistrates' court we should not be minimising the seriousness of this case but should suggest the Crown Court as being more suitable given that the death of a person is involved.

The case, as recognised by the CPS, was one of momentary inattention, and the Sentencing Guidelines suggested a community order. It was sent to the Crown Court, 
and the defendant, after pleading guilty, was sentenced to a 12 month community order and was disqualified from driving for 12 months.

Prosecutors are likely, therefore, to frame their recommendations accordingly. A number of prosecutors indicated in interview that magistrates are unlikely to retain jurisdiction for these cases. As one stated, 'to be honest it's very rare for magistrates to accept jurisdiction; very, very rare', but not impossible:

I managed to persuade a District Judge. I went over and did the hearing myself and it was an 80-something-year-old driver who pulled out into the path of a speeding motorcyclist; case of momentary inattention on the part of the defendant in front of a speeding motorcyclist and I managed to persuade the District Judge to accept jurisdiction but then the defendant elected.

In explaining magistrates' reticence to keep cases, this prosecutor noted that 'it's death' and 'it's going to involve complicated evidence and reconstruction analysis.' Another prosecutor noted that magistrates 'are wary of fatality cases', even though they would deal with them when they were simply careless driving cases. Barristers and defence solicitors also expressed similar sentiments. One defence solicitor said, 'they're lay people and involving a death' will mean that they will 'err on the side of caution and send it to the Crown Court.'

Prosecutors are unlikely to recommend that magistrates retain jurisdiction if they believe that this is likely to be ignored. One prosecutor in interview noted that most of these cases would be regarded as unsuitable for the magistrates' courts, 'and the magistrates make that decision, normally on prosecution representations that they're not suitable.' Furthermore, prosecutors 'do represent far more often than not that they 
are not suitable and the magistrates will tend to agree with that.' Feedback loops that reinforce a particular court culture do influence courtroom decision-making generally (Hucklesby, 1997; McConville et al., 1994) and this may explain the high level of agreement between prosecutors and magistrates for mode of trial decisions (Cammiss and Stride, 2008). However, not all prosecutors second-guess the bench. We saw above how a prosecutor managed to persuade a District Judge to accept jurisdiction, and other prosecutors told similar stories about magistrates who declined jurisdiction despite a recommendation to the contrary: 'I can see on our case analysis they've made clear representations that it was suitable, and the bench has just declined jurisdiction.' Nevertheless, some prosecutors believed that the Crown Court was the most appropriate venue: 'if I'm going to have a trial on this I'd far rather have it in a Crown Court and I think that although they're exposing themselves to a higher sentence I think most defence lawyers are happier having the trial at the Crown Court.' Such reluctance to try these cases in the magistrates' court may well not apply if a District Judge presides: 'If I can guarantee a District Judge [laughs], which I can't, I might be more happy to have it in the magistrates' court.' Research shows that, after accounting for case features, District Judges are not more likely to retain jurisdiction when compared to lay magistrates (Cammiss and Stride, 2008).

Explaining the decision to families was also a factor to be considered by the CPS:

I appreciate that a family would be surprised that a prosecutor would be representing the matter suitable for summary trial when new legislation had been introduced to allow imprisonment to be imposed and to allow a Crown Court to deal with such cases and even alarmed that the prosecutor represented no aggravating features, which would of course mean 
no other aggravating features other than the death of the victim which was represented in the actual charge.

Similarly, in a case where the prosecution recommended summary trial the prosecutor endorsed the file that this 'may be most difficult for [the family] to understand'. In interview, prosecutors expressed similar sentiments, while emphasising that family members' views were not determinative as allocation is 'very much a legal judgement' and 'I always know that the family invariably will want that case at the Crown Court; that isn't something that should be taken into account at venue.' The implication here is that families want 'their' case to be dealt with in the Crown Court due to the higher sentences available, but families also prefer the Crown Court because they see this as recognition that theirs is a serious case which deserves to be dealt with through the 'public face' (Sanders, Young and Burton 2010, 553) of the criminal justice system.

If a defendant is intending to maintain his or her innocence and face a trial, there are good reasons for her to prefer trial by jury in the Crown Court. Although this is a gamble, due to the higher available sentences in the Crown Court, acquittals are more common there, with 45 per cent of cases resulting in acquittal in the Crown Court compared to 39 per cent in the magistrates' court (Crown Prosecution Service, 2013). The offence of CDCD is one which involves an assessment which could be seen as 'supremely' a jury question: whether the defendant has driven below the standard of a competent and careful driver? The defendant may prefer to have this answered by twelve of his peers, in the same way that, for theft, the question of dishonesty is a moral one best answered by a jury. Juries are expected to address difficult questions: 
such as whether a defendant has acted dishonestly, by reference to contemporary standards, or whether he has acted in reasonable self-defence, or, when charged with causing death by dangerous driving, whether the standards of his driving fell far below what should be expected of a competent and careful driver (Judge LJ, $R$ v Misra and Srivastava [2004] EWCA Crim 2375 [2005] 1 Cr App R 21, 336).

The preference of both defendants and prosecutors to take these cases to the Crown Court is quite understandable. But this does not explain why a guilty plea is usually entered once the case gets there, dispensing with the need for a jury to address these difficult questions.

On defence practices, there is evidence that defendants are making decisions with an information deficit, thereby prompting an early not guilty plea to enable a more informed decision later. As one prosecutor noted in interview,

it's a serious charge, because it carries 5 years potentially, and they could get committed for sentence anyway, so I think there's a safety first tactic on the defence side of things, which is to procrastinate, wait for it to go to the Crown Court. Bear in mind also that at that stage, although they'll get initial details of the prosecution case, they won't have every detail about everything, so they might be wary about what exactly they're pleading to and what they're admitting.

In case A20 the defence initially indicated a not guilty plea while waiting for medical evidence on the cause of death. Deep vein thrombosis was diagnosed as the medical cause of death, resulting from immobility caused by injuries sustained in the collision. The defence sought expert opinion on whether the treatment was appropriate and, once it was confirmed that the treatment was not negligent, a guilty plea was entered. 
If the defence were able to wait for expert opinion before entering pleas (mode of trial is only considered after a not guilty plea or a failure to indicate a plea), then guilty pleas could be offered at an earlier stage in the process. Since the implementation of the Narey reforms, defendants enter a plea early (Home Office, 1997). In a previous mode of trial study, pleas could be offered on a Tuesday concerning allegations of criminal behaviour the previous weekend (Cammiss, 2009). Given the complex nature of the investigation of road traffic collisions, there was a greater delay here, with the time between the incident and the charging decision usually taking four to six months (with some notable exceptions). Nevertheless, once a decision to charge has been made, the first court appearance takes days, and the entering of pleas and mode of trial can take place on the first hearing. Permitting the commissioning of defence experts, while delaying the process, would allow for a plea to be entered with all of the appropriate information and evidence to hand. Expecting the defence to commission an expert before charge is unlikely to be regarded as viable, as this will lead to a waste of resources if the defendant is not charged. Additionally, any defence expert is only likely to be able to work with the data collected by the police expert, so that the defence cannot instruct their own expert until full disclosure has occurred.

Of course, some defendants may plead not guilty because they intend to contest the charge and elect to take advantage of jury trial. In the words of one prosecutor:

If I were defending, as I did do for 10 years, I'd elect if the Crown didn't ask for it to go to the Crown Court. I'd sooner take my chances with a jury than mags, particularly on issues such as the quality of driving; with juries I think you always stand the chance of 'there but for the grace of God' principle; they'll be thinking about their driving. 
However, while some defendants may do this, we have seen how few maintain innocence throughout, the vast majority of defendants pleading guilty eventually. This raises the issue, identified by Hedderman and Moxon (1992), of defendants electing only to subsequently plead guilty. When electing to take advantage of jury trial, one runs the risk of a higher sentence if convicted. Failing to put the prosecution case to the test leaves defendants at risk of receiving a more severe sentence, without the associated benefit of an increased chance of acquittal.

In case A02 the defendant elected Crown Court trial only to later plead guilty. The defendant had struck an elderly pedestrian whilst driving at slow speed in a car park. In interview, she maintained that the deceased simply walked out in front of her and she had no time to react. When shown CCTV footage of the collision she conceded that it appeared that the deceased had not just stepped off the kerb immediately in front of the defendant, but had already begun to cross and was there to be seen. Despite this, the defence statement submitted prior to trial was that the deceased had stepped into the defendant's path. It is not clear what influenced the later decision to plead guilty, and whether it was a question of obtaining a defence expert's view of the CCTV footage. The Senior Investigating Officer commented, however, that she probably changed her plea due to defence counsel advice on the strength of the evidence and the likely sentence after trial. In the event, the defendant received a two year community order.

As noted above, a number of triable either-way cases sentenced in the Crown Court receive sentences within the powers of magistrates. This occurred frequently in our 
sample, and at a greater rate than Ministry of Justice figures (Moreton, 2012). The reasons for this are complex: guilty plea discounts, the reticence of magistrates to accept jurisdiction, and the hesitancy of prosecutors to recommend that magistrates accept jurisdiction. On the guilty plea discount, one prosecutor noted that with 'a guilty plea there's an awful lot of credit in cases like this'. Case C32 is an example of a case sentenced in the Crown Court, with a disposal within the powers of the magistrates. The defendant pleaded guilty to $\mathrm{CDCD}$ and received a 12 month Community Order with 6 months supervision, 120 hours of unpaid work and disqualification for 18 months. The prosecutor recommended Crown Court trial, as on the 'guidelines I would put it at the top end of level 2 where the likely sentence will be more than $12 \mathrm{mths}$ '. Credit should have been given for the guilty plea, and the sentencing judge may not have seen the facts in the same light. Furthermore, the prosecutor may not have known about mitigating circumstances. Indeed, for the mode of trial decision, these were (at the time of the study) irrelevant, as the magistrates made their decision on the basis that the prosecution could prove its case and it was not for the defence to argue these points.

Making the mode of trial decision on the basis that the prosecution can prove its case assists administrative convenience. Allowing the defence to question the prosecution's version of events could lead to a much longer allocation hearing, and this would not be welcomed in busy magistrates' courts (Cammiss, 2006). Magistrates are concerned that this would result in a 'mini-trial' with uncertainty created on how to decide evidential disputes (Moreton, 2012: 14 and 15). It would be difficult to expect the defence to challenge the prosecution's evidence early in the case, particularly if awaiting expert reports. Furthermore, the defence would not want to 
raise mitigating circumstances while denying guilt, given the contradictions this would raise (Moreton, 2012).

\section{Mode of Trial Policy: Swift and Sure Justice}

The recent Ministry of Justice White Paper, Swift and Sure Justice (Ministry of Justice, 2012) is a continuation of ongoing political rhetoric reflected in the much abused aphorism that 'justice delayed is justice denied' (Ministry of Justice, 2012: 3). The Government claims that this new emphasis upon the swift delivery of justice is based upon admiration for the response of the courts to the riots in August 2011 (Ministry of Justice, 2012), when '[p]roceedings that might normally take two weeks... lasted 15 minutes' (Bowcott, 2011). While the response of the criminal justice system to the riots was undoubtedly influential, we can see pronouncements on the 'need for speed' in earlier policy documents and initiatives, such as the Narey reforms, 'Criminal Justice: Simple Speedy Summary (CJSSS)' and 'Stop Delaying Justice (SDJ)' (Home Office, 1997, Department for Constitutional Affairs, 2006; Ministry of Justice, 2012). Similarly, changes in the Criminal Procedure Rules aim to speed up proceedings in the Crown Court, with an emphasis upon case management and early guilty pleas (McEwan, 2011). Alongside these reforms, we can see ongoing concern with the problem of 'cracked trials' (Auld, 2001; Home Office, 2002; Ministry of Justice, 2010; Ministry of Justice, 2012). Similar concerns are expressed in debates on mode of trial and the 'correct' allocation of either-way cases between the magistrates' court and the Crown Court (Ministry of Justice, 2010; Ministry of Justice, 2012). 
Our data suggests that, for causing death by driving offences, the mode of trial decision is made within the context of a procedure where the desire to ensure that cases are processed quickly is contributing to delay and further unintended outcomes; the 'need for speed' is actually contributing to delay, inappropriate allocation decisions and cracked trials.

Mode of trial has been regarded by policy makers as problematic for some time. Crown Court delays, the cost of proceedings, inappropriate allocation decisions by magistrates and defendants 'playing the system' have all been identified as reasons to restrict the number of cases that are sent to the Crown Court (Riley and Vennard, 1988; Hedderman and Moxon, 1992). Magistrates are sending cases to the Crown Court only for large numbers of defendants to receive a sentence within the powers of the magistrates' court. Hedderman and Moxon (1992) noted that 52 per cent of defendants who were committed to the Crown Court in either-way cases received immediate custodial sentences, and a number of these will have been for less than six months, so that more than half of all sentences were within the powers of magistrates. According to Flood-Page and Mackie (1998) 62 per cent of defendants sentenced in the Crown Court for either-way offences received a sentence within the powers of the magistrates' court, while more recently Moreton (2012) reports a much lower figure of 35 per cent. Our data shows how causing death by driving offences share this problem of cases being sent to the Crown Court only to receive a disposal within the powers of magistrates' courts, but the problem is more pronounced for these cases. 
Similarly, there has been a longstanding claim that defendants elect Crown Court trial only to subsequently plead guilty once the case is sent to the Crown Court. Riley and Vennard (1988) noted that 78 per cent of all defendants pleaded guilty after electing jury trial while Hedderman and Moxon (1992) reported that, of defendants who elected, 70 per cent pleaded guilty to all charges while a further 14 per cent offered mixed pleas. However, their sample concerned convicted defendants, and excluded those who elected, maintained a not guilty plea and were subsequently acquitted. In short, policy makers have wanted to restrict the number of cases sent to the Crown Court and to dissuade defendants from electing jury trial. Our study reflects these concerns, in that the evidence shows how defendants may well elect Crown Court trial only to subsequently plead guilty.

Likewise, governments have been concerned with the phenomenon of cracked trials. These occur when the defendant pleads guilty at the door of the court, or the prosecution drop the case, resulting in wasted court resources and witnesses and victims are inconvenienced. In 2010, 43 per cent of trials cracked, and of these 63 per cent were the result of defendants entering guilty pleas (Ministry of Justice, 2011). Again, our data provides further evidence of this problem.

\section{Implications of the study}

We have argued that mode of trial decision-making for the new causing death by driving offences shares a number of characteristics with allocation decisions for 'mainstream' offences. A large proportion of cases sent to the Crown Court are 
sentenced within the powers of the magistrates' court, and defendants are electing Crown Court trial only to subsequently plead guilty. However, these new offences are more 'marked' in this respect; for instance, more sentences are imposed in the Crown Court within the powers of magistrates in this sample compared to Moreton's (2012) figures, and there are a number of reasons for this. There is evidence to suggest that mode of trial is taking place at a time when the defence are still unclear as to the strength of the evidence, promoting a 'play it safe' approach. One strand of our argument is that an undue focus upon 'swift justice' generates later problems. If one of the aims of the statutory charging scheme in the Criminal Justice Act 2003 was to get the charge right from the start, to avoid cracked trials and unnecessary committals (Home Office, 2002), allowing the defence space to consider their response with sufficient information is equally important. While the causing death by driving offences we have studied do raise issues specific to these offences, we can see echoes of the problems with mode of trial generally (Cammiss, 2006).

For instance, we have noted how the bench make their decision on the assumption that the prosecution can prove their case. Concerns on this are not new (Cammiss, 2006); , there is evidence that some magistrates find this frustrating, and that this may lead to inappropriate cases being sent to the Crown Court (Moreton, 2012). However, changing the procedure to allow for a fuller defence role would not necessarily change the outcome. Magistrates stated that this reform would not amend how they made their decision, while others wondered how they would adjudicate between the different accounts produced (Morton, 2012). Nevertheless, the new Consolidated Criminal Practice Direction states that the bench should take into account 'any 
representations by the parties' (2014; 9.10.(2)(e)(ii)) and the Allocation Guidelines were updated in 2012 so that:

The court should assess the likely sentence in the light of the facts alleged by the prosecution case, taking into account all aspects of the case including those advanced by the defence. (Sentencing Guidelines Council, 2008b: 18c).

These guidelines have been implemented nationally alongside the reforms in Schedule 3 of the Criminal Justice Act 2003 (Criminal Justice Act 2003 (Commencement No. 28 and Saving Provisions) Order 2012/1320; Criminal Justice Act 2003 (Commencement No. 29 and Saving Provisions) Order 2012/2574; and Criminal Justice Act 2003 (Commencement No. 31 and Saving Provisions) Order 2013/1103). In addition to Moreton's findings suggesting that this may make little difference, we can question whether there is any scope in busy magistrates' courts to adopt such an approach; mode of trial is regarded as a mundane process, with a minimal amount of time taken to make decisions (Cammiss, 2006). We doubt if courtroom professionals would welcome a more adversarial approach here or whether defence solicitors would have sufficient information to challenge the prosecution's case. Furthermore, in cases such as these, we doubt whether defence solicitors would want to challenge the prosecution. To quote one prosecutor:

it is taking the prosecution's case at its highest, you know, at plea before venue, so it's generally not too difficult to get these cases in the Crown Court. It's just a matter of practical prosecuting really, and as I've said, even if there were cases where we were happy for them to be dealt with at the magistrates' court, by and large the defence will elect anyway. 
Turning to the option for retaining the case and then committing for sentence, this is something that was suggested in case A27. This is a little used option, although prosecutors may refer to this in borderline cases (Cammiss, 2009). Magistrates are reluctant to use this tactic as 'a decision to accept jurisdiction is essentially final' (Herbert, 2003: 319). This is reiterated in research undertaken by the Sentencing Council:

If the case subsequently needed to be committed to the Crown Court for sentencing, [magistrates] described feeling as if the wrong (allocation) decision had been made. They described wanting:

...to make the right decision first rather than fall back on this [committing for sentence] later on (Moreton, 2012: 9).

When consulting on allocation guidelines, the Sentencing Council noted that 'magistrates may be cautious about accepting jurisdiction for fear that they may potentially create a legitimate expectation that the defendant will be sentenced in the magistrates' court' (Sentencing Council, 2011: 9). However, they also stated that 'no such expectation can arise where a defendant is clearly cautioned by the court when it accepts jurisdiction that all options for sentence remain open to the court, including a later committal to the Crown Court for sentence' (Sentencing Council, 2011: 9). As a result, the Council amended the Allocation Guidelines to make it clear that the option of committal for sentence remains open after retaining jurisdiction and that when accepting jurisdiction the court, "should remind the defendant that all sentencing options remain open, including committal to the Crown Court for sentence" (Sentencing Guidelines Council, 2008b: 18c). How this will be interpreted remains to be seen, given the current belief that the mode of trial decision is final. Current 
guidance to practitioners seems to follow the approach outlined above, that magistrates should try and make the 'correct decision' at the outset. As noted above, the Allocation Guidelines have recently been implemented nationally alongside the reforms in Schedule 3 of the Criminal Justice Act 2003 and the abolition of committal proceedings for either-way offences (which are now to be sent to the Crown Court). As part of this process, a training package was organised for criminal justice professionals, including the document, 'Allocation, Sending for Trial and Committal for Sentence' (Judicial College, 2012). It states that committal for sentence:

should not ordinarily be used where the defendant... is convicted after summary trial because the allocation decision has been made already in those cases. Legally it is still available, but the court will need to justify changing the original decision based on matters that have since come to light. This will be rare (Judicial College, 2012: 16).

This seems to run counter to the official guidance issued by the Sentencing Council, and is more consistent with current practice. It is also further evidence of the justifiable belief that it is problematic to commit for sentence after accepting jurisdiction. Defendants who consent to summary trial should know that they are more likely to be convicted, but that sentencing powers in the magistrates' courts are limited to six months imprisonment. If magistrates accept jurisdiction, knowing that they are likely to commit for sentence if the defendant is convicted, this is a bad deal for the defendant.

The second strand of our argument is that the issues uncovered in our discussion reflect the notion that it was misconceived to classify these offences as triable eitherway. In cases involving fatalities it appears that magistrates are not only concerned 
with the need to come to the right outcome regarding sentencing. These cases are seen as serious enough to warrant trial in the Crown Court and the gravitas that such trial entails, either due to genuine concern for the bereaved family's needs, or because of a reluctance on the part of the magistrates to deal with death. That these cases may well later end up being sentenced within the powers of magistrates does not, in itself, signify that the 'wrong' decision as to case allocation was made, inasmuch as whether justice is seen to be done does not depend wholly on the punishment meted out following conviction, but can be influenced by the process. Defendants accused of an offence which labels them as causers of death are likely to want trial by jury, particularly given that many of them have no previous convictions (Padfield 2001: 607). Our findings confirm those of an earlier study into offences of causing death by dangerous driving, where defendants rarely disputed that they were involved in the collision, but rather that their driving fell far below the standard of the careful and competent driver. An expert could be commissioned to challenge the prosecution's case, but if the expert agreed with the prosecution's version of events, the defendant was left with little choice but to plead guilty (Cunningham 2008).

With causing death by careless driving, given the low degree of culpability alleged, the defendant might be even more reluctant, when initially charged with the offence, to admit even to himself that he has caused the death of another human being, let alone to do so publicly in court. With time, legal advice, and the contribution of expert witness opinion, he may come to believe that it is in his best interests to plead guilty, and it is likely that he will be sincerely remorseful (Padfield 2011: 607). Bereaved families will want to see that their case 'matters' enough for it to be dealt with in the Crown Court, rather than brushed aside as a 'trivial' matter to be dealt 
with in the magistrates' court. What is clear from the sentencing decisions in these cases is that judges find them some of the most difficult with which they will have to deal, and are often keen to stress that the sentence they have decided to pass is in no way intended to reflect the loss of life. If this is difficult for professional judges in the Crown Court, it is unsurprising that lay magistrates will want to avoid this responsibility.

\section{Conclusions}

In this paper we have explored mode of trial decision-making for the two new causing death by driving offences, and in addition to being able to shed-light on the decisionmaking processes particular to these unusual offences, have also tried to use these two offences as a lens for viewing the mode of trial decision generally. We have looked to magistrates and prosecutors' decision-making and concluded that there appears to be an unwillingness to accept that these cases are suitable for summary trial, despite the Sentencing Guidelines which suggest that where there are no particularly aggravating case features, these offences are suitable for trial in the magistrates' court. On the part of magistrates, we have questioned whether they are unwilling to accept such cases because death is involved, the possibility of complex forensic evidence submitted in any subsequent trial, and the belief that magistrates are already accepting cases at the edge of their competence. For defendants, we have seen how many are electing Crown Court trial, only subsequently to plead guilty, and we have suggested the plea before venue hearing takes place in the absence of full information, causing defendants to take a 'play it safe' approach. 
England and Wales has adopted a more punitive stance in relation to drivers causing death on the roads than other European countries (van Dijk and Wolswijk 2014), and there appears to be no let-up in this regard. Most recently, the Government has announced that the maximum penalty for causing death by disqualified driving will be increased to 10 years' imprisonment (Ministry of Justice 2014), by way of creating a new separate indictable only offence, whilst at the same time creating a new triable either-way offence of causing serious injury by disqualified driving with a maximum penalty of two years' imprisonment (Criminal Justice and Courts Bill, clause 28 (as amended in committee, 31 July 1014), to insert s.3ZC and s.3ZD into the Road Traffic Act 1988). As predicted before the new causing death by driving offences came into force (Cunningham 2007), little has been achieved in terms of satisfying public demand for heavier sentences for drivers who kill, given that so many cases fall into the bottom category in the sentencing guidelines and avoid a custodial sentence. The mismatch between the sentence passed in these cases, and the venue for such sentencing can, to some extent, be explained by the unusual nature of the offences and the fact that the devastating impact on bereaved families is not proportionate to the blameworthiness of the offender in being guilty of a moment's inattention.

\section{Funding}

This work was supported by the Arts and Humanities Research Council [AH/I023147/1 to Kyd Cunningham]; and the Society of Legal Scholars [to Kyd Cunningham].

\section{Acknowledgements}


The completion of this work was facilitated by research leave from the University of Leicester [for Kyd Cunningham].

\section{References}

Auld, L.J. (2001) Review of the Criminal Courts of England and Wales.

Bowcott, O. (2011) 'Attorney general calls for boost to magistrates' sentencing powers', The Guardian, September 8.

Cammiss, S. (2006) "II Will in a Moment Give You the Full History”: Mode of Trial, Prosecutorial Control and Partial Accounts', Criminal Law Review 38-51.

Cammiss, S. (2007) 'Deciding Upon Mode of Trial', Howard Journal of Criminal Justice 46(4): 372-384.

Cammiss, S. (2009) Determining Mode of Trial: Exploring Decision Making in Magistrates' Courts. Saarbrucken: VDM.

Cammiss, S. and Stride, C. (2008) 'Modelling Mode of Trial'. British Journal of Criminology 48(4): 482-501.

Crown Prosecution Service (2013) Crown Prosecution Service Annual Report and Accounts 2012-13. London: CPS. 
Cunningham, S. (2007) 'Punishing Drivers Who Kill: putting road safety first?' Legal Studies 288-311.

Cunningham, S. (2008) Driving Offences: Law, Policy and Practice, Aldershot: Ashgate.

Department for Constitutional Affairs (2006) Delivering Simple, Speedy, Summary Justice. London: Department for Constitutional Affairs.

Department for Transport (2013) Reported Road Casualties Great Britain: 2012. London: Department for Transport.

Emsley, C. (1993), “"Mother, What Did Policemen Do When There Weren't Any Motors?" The Law, the Police and the Regulation of Motor Traffic in England, 19001939’ The Historical Journal 36:2, 357

Flood-Page, C. and Mackie, A. (1998) Sentencing Practice: An Examination of Decisions in Magistrates' Courts and the Crown Court in the mid 1990's. Home Office Research Study No. 180. London: Home Office.

Foreman-Peck, J. (1987), 'Death on the Roads: Changing National Responses to Motor Accidents' in Barker, T. (ed.), The Economic and Social Effects of the Spread of Motor Vehicles (London: Macmillan) 
Hedderman, C, and Moxon, D. (1992) Magistrates' Court or Crown Court: Mode of Trial Decisions and Sentencing. Home Office Research Study No. 125. London: HMSO.

Herbert, A. (2003) 'Mode of Trial and Magistrates' Sentencing Powers: Will Increased Sentencing Powers Inevitably Lead to a Reduction in the Committal Rate?', Criminal Law Review 314-325.

Herbert, A. (2004) 'Mode of Trial and the Influence of Local Justice', Howard Journal of Criminal Justice 43(1): 65-78.

Home Office (1997) Review of Delay in the Criminal Justice System: A Report. London: Home Office.

Home Office (2002) Justice for All. CM 5563. London: HMSO.

Home Office (2005), A Summary and Next Steps: The Review of Road Traffic Offences Involving Bad Driving London: Home Office.

Hucklesby, A. (1997) 'Court Culture: An Explanation of Variations in the Use of Bail by Magistrates' Courts', Howard Journal of Criminal Justice 36(2): 129-145.

Ipsos Mori (2012) The Strengths and Skills of the Judiciary in the Magistrates' Courts. Ministry of Justice Research Series 9/11. London: Ministry of Justice. 
Judicial College (2012) Allocation, Sending for Trial and Committal for Sentence: Criminal Justice Act 2003. Supporting Materials (Legal Adviser Training). London: Judicial College.

Kyd Cunningham, S. (2013) 'Has law reform policy been driven in the right direction? How the new causing death by driving offences are operating in practice?' Criminal Law Review 712-729.

McBarnet, D. (1981) Conviction: Law, the State and the Construction of Justice. London: McMillan.

McConville, M., Hodgson, J., Bridges, L. and Pavlovic, A. (1994) Standing Accused: The Organisation and Practices of Criminal Defence Lawyers in Britain. Oxford: Clarendon.

McEwan, J. (2011) 'From Adversarialism to Managerialism: Criminal Justice in Transition', Legal Studies 31: 519-546.

Magistrates' Association (2012) Active, Accessible, Engaged: The Magistracy in the $21^{\text {st }}$ Century. London: Magistrates’ Association.

Ministry of Justice (2010) Breaking the Cycle: Effective Punishment, Rehabilitation and Sentencing of Offenders. Cm 7972. London: Ministry of Justice. 
Ministry of Justice (2011) Judicial and Court Statistics 2010. London: Ministry of Justice.

Ministry of Justice (2012) Swift and Sure Justice: The Government's Plans for Reform of the Criminal Justice System. Cm. 8388. London: Ministry of Justice.

Ministry of Justice (2014) Press release: Justice for victims of banned drivers available at https://www.gov.uk/government/news/justice-for-victims-of-banneddrivers (last accessed 16/5/14).

Moreton, K. (2012) Research into the Allocation Process and Decision-making. Sentencing Council Analysis and Research Bulletin. London: Sentencing Council.

Padfield, N. (2011) 'Time to Bury the Custody “Threshold”?', Criminal Law Review 593-612.

Perkin, H. (1976), The Age of the Automobile (London: Quartet Books)

Riley, D. and Vennard, J. (1988) Triable-Either-Way-Cases: Crown Court or Magistrates' Court. Home Office Research Study No. 98. London: HMSO.

Sanders, A., Young, R. and Burton, M. (2010) Criminal Justice (4 ${ }^{\text {th }}$ ed.). Oxford: OUP. 
Sentencing Council (2011) Overarching Guidelines Professional Consultation: Allocation, Offences Taken Into Consideration and Totality. London: Sentencing Council.

Sentencing Guidelines Council (2008a) Causing Death by Driving: Definitive Guideline. London: Sentencing Guidelines Council.

Sentencing Guidelines Council (2008b) Magistrates' Court Sentencing Guidelines: Definitive Guideline. London: Sentencing Guidelines Council. (Updated in 2012).

van Dijk, A. and Wolswijk, H. (2014) Criminal Liability for Serious Traffic Offences. Essays on Causing Death, Injury and Danger in Traffic (Eleven International Publishing, forthcoming) 
Table 1

\begin{tabular}{|c|c|c|c|c|}
\hline & $\begin{array}{l}\text { CDCD cases } \\
\text { study sample }\end{array}$ & $\begin{array}{l}\text { CDCD cases } \\
\text { CPS } \\
\text { monitoring data }\end{array}$ & $\begin{array}{l}\text { CDUD study } \\
\text { sample }\end{array}$ & $\begin{array}{l}\text { CDUD } \\
\text { monitoring data }\end{array}$ \\
\hline $\begin{array}{l}\text { Number of } \\
\text { cases charged }\end{array}$ & 22 & 55 & 7 & 17 \\
\hline $\begin{array}{l}\text { Prosecutor } \\
\text { recommended } \\
\text { SST }\end{array}$ & 3 & Unknown & 2 & Unknown \\
\hline $\begin{array}{l}\text { Sentenced in } \\
\mathrm{MC}\end{array}$ & 4 & 25 & 0 & 5 \\
\hline $\begin{array}{l}\text { Sentenced in } \\
\text { CC with } \\
\text { sentence } \\
\text { available in } \\
\text { MC }\end{array}$ & 11 & 15 & 5 & 8 \\
\hline $\begin{array}{l}\text { Sentenced in } \\
\text { CC with } \\
\text { sentence } \\
\text { exceeding } \\
\text { that available } \\
\text { in MC }\end{array}$ & 5 & 15 & 1 & $\begin{array}{l}3(+1 \text { where } \\
\text { data on } \\
\text { sentence } \\
\text { unavailable) }\end{array}$ \\
\hline $\begin{array}{l}\text { Guilty plea in } \\
\text { CC }\end{array}$ & 12 & 28 & 6 & 7 \\
\hline $\begin{array}{l}\text { Not guilty } \\
\text { plea in CC }\end{array}$ & 3 & 2 & 1 & 1 \\
\hline $\begin{array}{l}\text { Acquittals, no } \\
\text { evidence } \\
\text { offered and } \\
\text { cases dropped }\end{array}$ & 2 & 0 & 1 & 0 \\
\hline
\end{tabular}

